\title{
The Moderating Role of HOTS Training Program on Teacher Efficacy and Teacher Effectiveness Relationship
}

Rahida Aini Mohd Ismail (Corresponding Author)

School of Government, Universiti Utara Malaysia

Tel: +60-174-708-150 E-mail: rahidaismail@gmail.com

Assoc. Prof. Dr. Rozita Arshad

Dept. of Public Management, School of Government, Universiti Utara Malaysia

Tel: +60-134-899-696 E-mail:roz@uum.edu.my

Prof. Dr. Zakaria Abas

Dept. of Management Accounting and Quality Management,

School of Accountancy, Universiti Utara Malaysia

Tel: +60-194-172-466 Email: zakaria@uum.edu.my

Received: May 19, 2017 Accepted: June 1, 2017 Published: December 21, 2017

doi:10.5296/jpmr.v3i2.11251ＵRL: http://dx.doi.org/10.5296/jpmr.v3i2.11251

\begin{abstract}
There has been an increased awareness from mass media, employers, educationalists, and researchers lately on Higher Order Thinking Skills (HOTS), as a prerequisite for the 21st century workforce. HOTS have portrayed a huge industry demand and the major goal of every educational institutions in providing education is to foster problem solving, critical thinking, and innovative skills among the students. Without a doubt, teachers are the most valuable resource accessible to all schools that shoulder the responsibility of molding and shaping students as individuals toward producing modern workforce who are good critical thinkers, creative, competent communicators and good problem solvers. Hence, the purpose of HOTS Training Program is to develop and improve the job-related knowledge, skills, and abilities to enhance teachers' performance and ultimately improve student learning. The
\end{abstract}


present study examines the moderating effect of HOTS training program on the relationship between teacher efficacy and teacher effectiveness. Hierarchical Regression analysis was used to determine whether HOTS Training Program is a moderator for the model to modify or strengthened the relationship between the Independent and Dependent Variables.

Keywords: Higher Order Thinking Skills (HOTS), HOTS Training Program, Teacher Efficacy, Teacher Effectiveness

\section{Introduction}

A nation's human capital is largely built by upon its education system, of which acts as a fundamental driver for economic growth (The World Bank, 2013). In fact, there has been an increased awareness from mass media, employers, educationalists, and researchers lately on HOTS, as a prerequisite for the $21^{\text {st }}$ century workforce (Pezhman, Zara \& Moomala Othman, 2015). In determining the success of the education system in Malaysian schools, students of today are expected to meet higher standard. Hence, teachers' training program plays a vital role to develop the professionalism of teachers to face the current challenges to guide students towards higher standards of learning and self-development (Che Mohd Zulkifli, 2014).

In the context of Malaysia's HOTS training program, there has been considerable efforts to prepare and upgrade teachers' professional skills and competencies (Rajendran, 2001). There were various short courses and workshops on teaching HOTS have been designed to prepare teachers to teach HOTS ever since the 1980's (Rajendran, 2001; Azlin, Haizir, Mohamad Ruzaini \& Nurazlina, 2014) but training them to teach specifically on HOTS started in 1994 at teacher education colleges (The World Bank. 2013, Seffetullah, Shahabuddin \& Hairul, 2015).

\section{Problem Statement}

The poor performance of Malaysian students in PISA or Performance International Student Assessment indicated that the lack of HOTS ability among students and more efforts from teachers are needed to ensure teaching effectiveness to elevate students' performance (Mohd Shafik, Mohamad Hisyam, Muhamad Furkan \& Nabilah, 2015). The Malaysian students scored below the international standard when the performance of the Malaysian education system effectiveness is assessed against student performance in all three subjects, namely: Mathematics, Science and Readings on internationally administered, PISA test (Micklewright, Jerrim, Vignoles, Jenkins, Allen, Ilie, Bellarbre, Barrera, \& Hein, 2014; Malaysia Education Blueprint, 2012). As a result teachers have been under a growing pressure to implement HOTS as an essential component in the curriculum delivery.

Based on Teaching and Learning International Survey (TALIS) report, over ninety percent of teachers participated in Professional Development each year (Malaysia Education Blueprint, 2012). Previous research has shown that teachers faced difficulty in student engagement, instructional strategy, and classroom management due to limited knowledge and skills in HOTS (Nyet, 2013; Nyet, Nazir \& Chin, 2015). In addition, there were many types of in-service training designed to facilitate teachers on the job training for efficiencies in schools 
but so far, they failed to provide effective classroom teaching (Rajendran, 2001; Rosnani, 2003; Yee, Jailani, Widad, Razali, Tee \& Mimi, 2012).

From a review of literatures reflected that there has been limited empirical research using Guskey's (2000) model that surveyed the moderating effects of HOTS training program on the relationship between teacher efficacy and teacher effectiveness. It is important to examine whether the moderating effect of HOTS training program can contribute in enhancing teachers' efficacies in secondary schools. The literature reviewed by previous researchers (Sarina \& Noraini, 2015; Abdul Talib, Rosma, Azli, Norazilawati \& Noraini, 2015) reflected that there were inconsistent findings on the moderating effects of training. HOTS training program is still limited, hence this leads to the researcher's interest in the usage of Guskey's model to test the level and the moderation effects of HOTS training program.

\subsection{Research Questions}

The research questions addressed in the present work are:

i. What is the level of HOTS training program received among teachers?

ii. Is there any moderating effect of HOTS training program on the relationship between teacher efficacy and teacher effectiveness?

\subsection{Research Objectives}

Generally, the objective of this study is to:

i. To describe the level of HOTS training program received among teachers

ii. To examine the moderating effect of HOTS training program on the relationship between teacher efficacy and teacher effectiveness.

\section{Literature Review}

\subsection{HOTS Training Program}

The term 'Training program' indicates as a set of activities and necessities that falls under the heading of 'professional development' (Ali \& Mansooreh, 2014). This organizational activity is a development opportunity; given to a staff for job enrichment to widen their knowledge, skills and techniques (Amadi \& Promise, 2013). The exposure of teachers in HOTS training program for instance, is not only to bring a deep impact on teachers' level of knowledge, but to keep them abreast of the new changes and improvements in the curriculum delivery to ensure teaching and learning quality.

\subsection{Policy Implementation in relation to HOTS}

According to Yaro, Rozita, and Dani (2017, p.3), "policy implementation is the routine governmental processes of putting the government's targeted goals into action which is usually done by government agencies or its officials in accordance with the stipulation of the law". The implementation of HOTS in the Malaysian education system is to lead to the achievement of the final educational output that is to produce a critical thinking society; to 
prepare students with real-life skills for tomorrow's knowledge-based economy, skillful in creative and innovative thinking and able to compete in the global labour market (Raja Abdullah \& Norma, 1993; Ganapathy \& Sarjit, 2014).

The execution of the policy initiatives such as HOTS as embedded in the curriculum development to enhance students' thinking skills in Malaysia is not new. In fact, the Ministry of Education $(\mathrm{MoE})$ has implemented several educational reforms in its education system to implement the teaching of thinking skills to develop students' HOTS since the 1980s. In ensuring rapid implementation of education policies for better student learning outcomes, the Integrated Curriculum for Secondary Schools (ICSS) in 1988, Vision 2020 (1991), the Critical and Creative Thinking Skills (KBKK) (1996), and 'Smart School' (1997) was introduced (Tan \& Siti Hajar, 2015). To further improve on HOTS, the Malaysian public examinations and school-based assessments in schools implemented test papers that streamlined with HOTS questions (MEB, 2012). HOTS questions would make up eighty percent of Form three central assessment (PT3), seventy-five percent of HOT questions for Malaysia Certificate of Education (MCE) core subjects, and fifty percent for MCE elective subjects (Natalya, 2014).

To nurture creative and analytical human capital, the Malaysian government has invested in Programmes such as i-Think project and Kemahiran Berfikir Aras Tinggi (KBAT) in schools to impart higher level of cognitive thinking skills to students (Hasnah \& Jamaludin, 2017). Malaysia in general has a centralized education system (Nooreiny \& Indira, 2015), and policies are made at the national level. Teachers are the internal stakeholders or one of the multiple actors, whom are responsible to ensure that the national education policy is accomplished at the local level. They play a significant role in influencing the educational outcomes, the improvement of the schools, and student achievements (Yaro, 2017).

Since the education for the future placed more emphasis on developing the students with creative and thinking minds, it is imperative to have teachers who can efficiently deliver the HOTS curriculum. As highlighted in the Malaysia Education Blue Print 2013-2025, education at all levels should develop HOTS in all subjects (MEB, 2012; Malaysia Report, 23 April 2012). Yaro (2017) stated, the roles of the government as employers of teachers is to ensure that these education stakeholders receive not only proper supervision, but also constant training, or re-training from time to time in order to maintain a high standard of teaching and to retain a high-quality teacher workforce.

In Malaysia, over ninety percent of teachers' participated in the professional development, and spend more than the Ministry-mandated requirement of seven days per year, about ten days each year on in-service training program that includes self-study, off-site workshops and school-based coaching activities (MEB, 2012). This explains that the in-service training is common in Malaysia, and teachers formally received such training annually. However, not much is known as to whether teachers are benefitting from valuable in-service training program.

Tajularipin, Vikneswary, Diwiyah, Raidah, and Suzieleez. (2017) claimed that teachers were aware in applying HOTS in their teaching but found it hard to use the right teaching method 
when the class is big, and each student has different level of abilities to grab the HOTS concept. This is supported by Abdul Talib et.al (2015) found that teachers teaching social science subjects were aware about the implementation of HOTS and innovation in subjects like history teaching but found majority of teachers (66.6 per cent) focused more on lower thinking skills, or better known as LOTS. Hence, it is important to examine the moderating effect of HOTS training program on the relationship between teacher efficacy and teacher effectiveness.

\section{Methodology}

This paper examines the level of HOTS training program among the secondary school teachers. In addition, it examines the moderating effects of HOTS training program on the relationship between teacher efficacy and teacher effectiveness.

\subsection{Research Design}

In this study, the researcher applied a quantitative method approach and distributed 500 questionnaire surveys to teachers as the respondents. Meanwhile, random sampling technique was chosen of which the respondents were drawn randomly from the target population. The researcher considered a quantitative survey using questionnaires is more appropriate because it allows respondents more time to think without having to rush to decide on their responses and hence, provide a more accurate data. As Yee et.al. (2012, p.199) lamented, "more data can be obtained in a short period of time and responses are found to be more consistent compared with data collected through observation".

\subsection{Participants}

The population of this study comprises all secondary school teachers teaching at national secondary schools in the Northern region of Kedah, Penang, Perlis and Perak. Teachers of the national secondary schools were chosen as the main target population because of their role as the policy implementers is to promote HOTS in their classroom lessons to enhance student's cognitive and intellectual growth (Abdul Talib et.al., 2015). Moreover, more than eighty percent $(80 \%)$ of the secondary schools in Malaysia are of the national type schools (Nuraini $\&$ Leong, 2016). In addition, these teachers have undergone HOTS training and they are obviously able to distinguish between effective and non-effective attributes of training. It is impossible to meet every teacher because the number of teachers is very large and spread all over the country. The four states have a total population $(\mathrm{N})$ of 43,600 secondary school teachers, therefore the schools were randomly selected throughout the states. Teachers were given their rights to choose whether to participate or not. Also, if there were any of the schools that chose not to participate in this research, then the next school in the randomized list would be selected.

The criteria for this study are based upon a desire to make changes for teachers to be more effective in bringing about better student achievements in HOTS. If teachers are exposed to effective training program, they are better equipped to help student achievements in HOTS. Secondary school teachers was chosen based on the fact that they were the disseminators of knowledge, and that the secondary education provides the foundation for students to develop 


\section{Macrothink}

their full potentials to be useful members in the society. Hence, the proposed population of this study concerned with the number of practicing teachers in the secondary schools in the northern region and the total collection of sample shown in Table 1.

Table 1. Actual Sample Size.

\begin{tabular}{llll}
\hline State & Teachers & Sample & Actual sample \\
\hline Kedah & 13,811 & 122 & 200 \\
Perak & 17,997 & 156 & 170 \\
Perlis & 2,259 & 19 & 40 \\
Penang & 9,533 & 83 & 90 \\
\hline TOTAL & 43,600 & 380 & 500 \\
\hline
\end{tabular}

Source: Malaysia Educational Statistics. (2014)

\subsection{Demographic information}

A total of 410 out of 500 secondary school teachers participated in this study, constituting a response rate of $82 \%$. The information obtained from the respondents indicated that teachers, as the internal stakeholders are the most important factor in delivering teaching quality for student learning outcomes (Fouzieh, Zurida, Sheikh Abdul Malik, Kourosh \& Sedigheh, 2013). Besides, their involvement in the training program is to ensure effective teaching (Tyagi, 2013).

Their demographic information was elicited through the first part of the survey found about $10 \%$ of respondents are aged between 21 and 30 years, $30.7 \%$ were aged between 31 and 40 years, $34.6 \%$ were aged between 41 to 50 years, and the remaining $24.6 \%$ are aged 51 years and older. This shows that majority of the teachers whom had undergone the HOTS training program are in their productive stage and should be able to contribute towards effective teaching practices. The demographic information on respondent's age is presented in Figure 1.

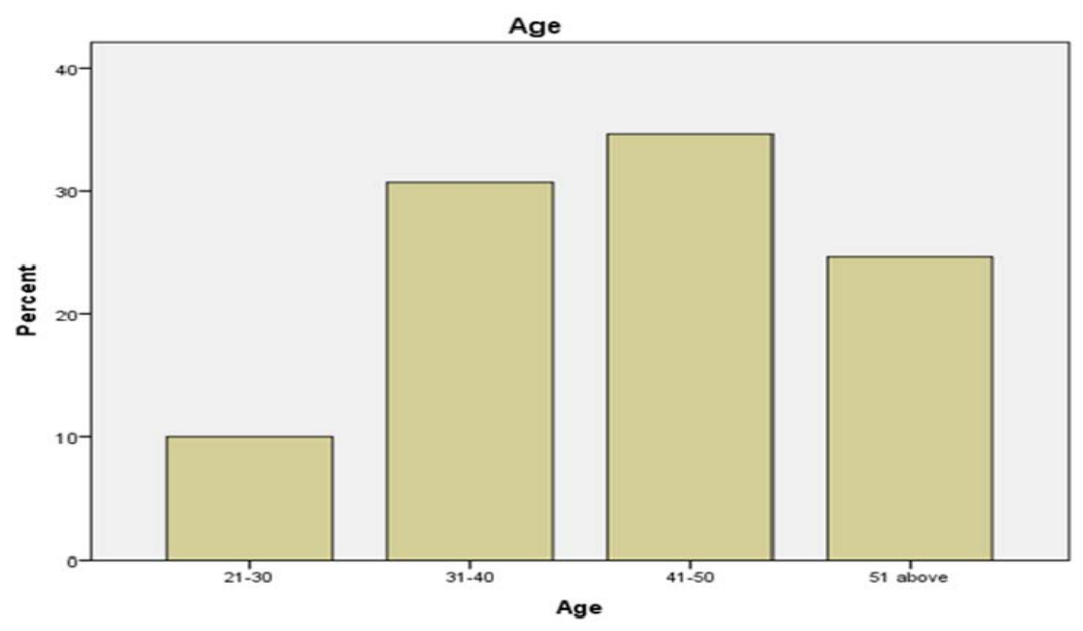

Figure 1. Respondents' Age 
The figure 1 shows that teachers of the age group between 41 to 50 years had the highest representation (almost $35 \%$ ). However, the least representation were teachers of the age group between 21 to 30 years $(10 \%)$. The table presented above suggests that majority of the respondents were mature and experienced teachers whilst minority were young teachers. This implies that the majority of the respondents in the secondary schools in the Northern region were filled up by matured and experienced teachers. Among the younger teachers between 21-30 years old and older teachers of 41-50 years old, the difference in scores between the two age groups is small, about $15 \%$. The difference in scores between younger teachers and older teachers (between 21-30 years old and older teachers of 41 to 50 years) is more pronounced than the other two age groups; $31-40$ years $(4 \%)$ and $41-50$ years $(10 \%)$. The graph presented in figure 1 suggested that mature teachers (age between 41 to 50 years) dominated the most in the delivery of HOTS teaching and learning process in the secondary schools.

\subsection{Descriptive analysis results of HOTS Training Program}

Table 2. Mean scores and standard deviations of the HOTS Training Variables

\begin{tabular}{ccc}
\hline Variables & Mean $(\mathrm{M})$ & Standard Deviation (SD) \\
\hline Reaction & 5.3659 & 0.75874 \\
learning & 5.4768 & 0.89488 \\
Organizational support & 5.8205 & 0.81859 \\
Knowledge and skills & 5.6434 & 0.76281 \\
Student learning & 5.6817 & 0.79888 \\
\hline
\end{tabular}

The Table 2 depicted the descriptive analysis using means scores and standard deviations of which the level of HOTS training program is found to be high. Teachers had a high level on the overall mean scores for all of the respective components of HOTS training program. The overall mean scores are higher than 5.0 and standard deviations are also high, which is close to 1.0. The level of HOTS training program is high in reaction, learning, knowledge and skills, organizational support, and perceptions of student learning. This study supports the findings by Asfaw, Argaw, and Bayissa (2015) on the impact of training and development on employee performance and effectiveness. Their study found that the training activities can help to increase the level of employees' potentials in performing their tasks and resulted in their effectiveness. In contrast, this study did not support the findings of Bikos, Tsigilis and Grammatikopoulos (2011) because only participants' reactions can enhance teacher efficacy beliefs and their capabilities in the Introductory Training Program but not on other training dimensions, like learning, behavior, and result. Therefore, the objective of this study has been achieved. This is followed by examining the moderation effects of the HOTS Training Program on the relationship between teacher efficacy and teacher effectiveness.

\subsection{Hierarchical regression}

Hierarchical regression, also known as a moderator; is considered to be a suitable technique to determine the moderating variables (Baron \& Kenny, 1986). In order to test whether 
HOTS Training Program moderates the relationship between Teacher Efficacy and Teacher Effectiveness, a three (3) step hierarchical regression by Cohen and Cohen (1983) and Cramer (2003) was conducted to determine if the percentage of variance in the dependent variable was explained by other variables when those variables were put into the regression analysis in a specific order.

When testing the moderating effect, there were three steps that needs to be considered. For instance, in step one, the direct effect of the three independent variables namely: efficacy student engagement, efficacy instructional strategy, and efficacy classroom management were regressed against the dependent variable (teacher effectiveness). Meanwhile in step two, the moderating variable (HOTS Training Program) was regressed against the dependent variable (Teacher Effectiveness) to assess whether the moderator has a significant direct effect on the dependent variable. In step three, both the independent and moderating variables were regressed against the dependent variable. The purpose of the regression process in the third step is to determine the interaction terms (multiplication of the independent variable and moderator variable) to seek for any additional variance explained. Before proceeding to get the interaction terms to measure the moderating effect, all the variables meant to be used were standardized. For moderator effect to be present, the interactions terms should be able to yield at least small increase in R square (Chaplin, 1991). According to Baron and Kenny (1986) a moderating effect takes place if the test in step 3 is significant. Similarly, Tabachnick and Fidel (2007) asserted that researchers should examine the t-value or p-value under the coefficient table when establishing a moderating effect.

Table 3. The Moderation Effects of HOTS Training Program on the Relationship between Teacher Efficacy (TEF) and Teacher Effectiveness (TE)

\begin{tabular}{cccc}
\hline Variables & \multicolumn{3}{c}{ Standardized Beta } \\
\cline { 2 - 4 } & Step1 & Step 2 & Step3 \\
\cline { 2 - 4 } TEF & $.785^{* * *}$ & Without interaction & With interaction \\
HOTS & & $.572^{* * *}$ & $.539^{* * *}$ \\
TEF x HOTS & & & $.384^{* * *}$ \\
$\mathrm{R}^{2}$ & .617 & $.377^{* * *}$ & $-.078^{* * *}$ \\
Adjusted R & .616 & .714 & .719 \\
$\mathrm{R}^{2}$ Change & .617 & .712 & .717 \\
F Change & 656.854 & .097 & $.005^{* * *}$ \\
Sig. F Change & $.000^{* * *}$ & 507.776 & 346.538 \\
\hline
\end{tabular}

Sig. level ***.001 $* * \mathrm{p}<0.01, \quad * \mathrm{p}<0.05$

An overall scanning of the interacting effects between HOTS Training program on the relationship between the Teacher Efficacy and Teacher Effectiveness, was carried out and reconfirmed the hierarchical regression results between Teacher Efficacy and Teacher Effectiveness. The independent variable were first entered in step 1, which explained 61.7 
percent of the variance. After entering the HOTS Training Program at step 2, the total variance as explained by the model was 71.4 percent. In step 3, the interaction terms were inserted, which resulted to an additional variance explaining up to 71.9 percent. There is a slight increase of $\mathrm{r}^{2}(.005)$ and the sig. F change from step 1 to 2 , and from step 2 to 3 was significant at the $1 \%$ level. However, upon scanning of the beta co-efficient for individual interaction terms between HOTS Training $\times$ Teacher Efficacy $(\beta=-.078, t=-2.756, p=.006)$ was significant at $\alpha=0.001$ level. The overall results of this study indicated support for all the moderating effects of HOTS Training Program on the relationship between Teacher efficacy (Efficacy student engagement, efficacy instructional strategy, and efficacy classroom management).

\section{Conclusion}

Extensive research has shown that the success of a country's education system depends on the effectiveness of the teachers (Dibaphile, 2012). Considering the educational context and expectations of our teachers today, teachers' abilities to promote HOTS in the classroom is important that would result in more analytical individuals who are competent to solve complex problems within their future workplace and within their roles as citizens in the social, political, and economic world (Ricci, 2014). This can be achieved by active participation of teachers in the HOTS Training program where they can deeply appreciate to continuously apply their HOT skills and utilized HOT knowledge as a result of training.

\section{References}

Abdul Talib, H, Rosma O., Azli A., Norazilawati, A., \& Noraini, M. N. (2015). Teachers' perception on Higher Order Thinking Skills as an innovation and its implementation in History teaching. Australian Journal of Basic and Applied Sciences, 9(32). Special 2015. 215-221.

Ali, K., \& Mansooreh, A. (2014). In-service training programs for Iranian EFL teachers revisited. International Journal of Asian Social Science, 4(10), 1062-1076.

Amadi, E. C., \& Promise, A. (2013). Professional development on teachers' academic performance in secondary schools in Etche local government area. International Journal of Education Learning and Development, 1(2), 19-23. www.ea-journals.org

Asfaw, A. M., Argaw, M. D., \& Bayissa, L. (2015). The impact of training and development on employee performance and effectiveness: A case study of district five administration office. Bole Sub-city, Addis Ababa, Ethiopia. Journal of Human Resource and Sustainability Studies, 3, 188-202. https://doi.org/10.4236/jhrss.2015.34025

Azlin, N., Haizir, H., Mohamad, R. A., \& Nurazlina, K. (2014). An Application of Bloom's Taxanomy in Generation and Assessment of Examination Question Items. International Journal of Innovative Computing, 4(1), 1-8.

Baron, R. M., \& Kenny, D. A. (1986). The moderator-mediator variable distinction in social psychological research: conceptual, strategic, and statistical considerations. Journal of 
$\begin{array}{llll}\text { Personality and Social } \quad \text { Psychology, } & \text { 51(6), }\end{array}$ https://doi.org/10.1037/0022-3514.51.6.1173

Bikos, Tsigilis \& Grammatikopoulos. (2011). The effect of an introductory training program on teachers' efficacy beliefs. International Journal of Humanities and Social Science, 1(14), $37-40$.

Chaplin, W. F. (1991). The next generation of moderator research in personality psychology. Journal of Personality, 59, 143-178. https://doi.org/10.1111/j.1467-6494.1991.tb00772.x

Che M.Z.C.O. (2014). The need for in-service teachers and it's effectiveness in school. International Journal for Innovation Education and Research, 1-8. www.ijier.net

Cohen, J., \& Cohen, P. (1983). Applied multiple regression/correlation analysis for the behavioral sciences (2nd ed.). Hillsdale, New Jersey: Erlbaum.

Cramer, D. (2003). Advanced Quantitative Data Analysis. Open University Press Maidenhead, $\mathrm{Ph}$.

Dibapile, W. T. S. (2012). Teacher Efficacy and Classroom Management among Botswana Junior Secondary School Teachers. PhD dissertation. University of Tennessee. http://trace.tennessee.edu/utk_graddiss/1520

Duron, Limbach \& Waugh. (2006). Critical thinking framework for any discipline. International Journal of Teaching and Learning in Higher Education, 17(2). 160-166. http://www.isetl.org/ijtlhe/ ISSN 1812-9129

Fouzieh, S., Zurida, I., Shaik, A. M. M. 1., \& Kourosh, F. V. (2013). An evaluation of the effectiveness of Teachers' Professional Development (TPD) in Iran using Akker Spider Web Model. International Journal of Human Resource Studies, 3(3).

Ganapathy, M., \& Sarjit, K. (2014). ESL students' perceptions of the use of Higher Order Thinking Skills in English Language Writing. Advances in Language and Literary Studies, 5(5), 80-87. ISSN: 2203-4714.

Hasnah Isnon \& Jamaludin Badusah (2017). Kompetensi guru Bahasa Melayu dalam menerapkan kemahiran berfikir aras tinggi dalam pengajaran dan pembelajaran. Jurnal Pendidikan Bahasa Melayu - JPBM (Malay Language Education Journal - MyLEJ), 7(1) (Mei 2017), 56-65. ISSN: 2180-4842.

Malaysia Education Blueprint, 2013-2025. (2012). Preliminary Report.

Micklewright, J., Jerrim, Vignoles, A., Jenkins, A., Allen, R., Ilie, S., Bellarbre, E., Barrera, F., \& Hein, C. (2014). Teachers in England's Secondary Schools: Evidence from TALIS 2013 Research report June 2014. UK: Institute of Education, University of London.

Mohd, S. Y, Mohamad, H. I., Muhamad, F. M. S., \& Nabilah, A. (2015). Science teachers' continuous professional development: nature of school based teacher training and its implementation. Full Paper Proceeding MISG-2015, 1, 94-106. Available online at www.globalilluminators.org 
Natalya, R. S. (2014). Game design as a tool to promote higher order thinking skills. International Journal for Innovation Education and Research, 2(6), 51-58.

Nooreiny, M., \& Indira Malani, M. (2015). Teacher's Belief of the new Standard Curriculum for Primary Schools (KSSR) in Teaching English as (ESL) in Malaysian Schools: A Qualitative approach. Asian Journal of Multidisciplinary Studies, 3(5).

Nuraini, M. Z., \& Leong, K. E. (2016). Malaysian Mathematics teachers; beliefs about the nature of teaching and learning. The Malaysian Online Journal of Educational Science, 4(1), 21-29. www.moj-es.net

Nyet, M. S. (2013). Exploring primary Science teachers' creativity and attitudes through responses to creative questions in University Physics Lessons. British Journal of Education, Society \& Behavioural Science, 3(1), 83-108.

Nyet, M. S., Nazir, A., \& Chin, L. C. (2015). The perceptions of pre-service and in-service teachers regarding a project-based STEM approach to teaching science. SpringerPlus, 4(8), doi:10.1186/2193-1801-4/8

Pezhman, Z., \& Moomala, O. (2015). Students' perceptions toward using classroom debate to develop critical thinking and oral communication ability. Asian Social Science, 11(9), 158-170.

Raja, A. Y., \& Norma, A. S. (1993). Towards achieving a critical thinking society in Malaysia: A challenge to school libraries and educational systems. Dreams and Dynamics. Selected Papers from the Annual Conference of the International Association of School Librarianship (22nd, Adelaide, South Australia, Australia, September 27-30, 1993)

Rajendran, N. (2001). The teaching of Higher-Order Thinking Skills in Malaysia. Journal of Southeast Asian Education, 2(1), 42-65.

Report on Education Reform and Process of Consultation. (2012). Education Reform in Malaysia Report (23 April 2012). Centre for Public Policy Studies, Asian Strategy and Leadership Institute (ASLI-CPPS) Association for the Promotion of Human Rights (PROHAM) Institute of Ethnic Studies, Universiti Kebangsaan Malaysia (KIT UKM).

Ricci, F. (2014). Cultivating critical thinking within organizations. 8-10 September. Istanbul, Turkey. Proceedings of SOCIOINT14-International conference on Social Sciences and Humanities, 47-74.

Rosnani, H. (2003). Malaysian teachers attitudes, competency and practices in the teaching of thinking. Intellectual discourse, 11(1).

Sarina, M. N., \& Noraini, N. (2015). Training as a moderator in the relationship between employee's collaboration, top management support and IT support with knowledge management in Malaysian public organization. International Academic Research Journal of Business and Technology, 1(2), 108-116. 


\section{Macrothink}

Seffetullah, K., Shahabuddin, H., \& Hairul, N. I. (2015). Malaysian adolescent students' needs for enhancing thinking skills, counteracting risk factors and demonstrating academic resilience. International Journal of Adolescence and Youth, (1), 32-47.

Tabachnick, G. G., \& Fidell, L. S. (2007). Using Multivariate Statistics (5th ed.). Boston: Pearson Education.

Tajularipin, S., Vikneswary, M., Diwiyah, M., Raidah, H., \& Suzieleez, S. A. R. (2017). Implementation of Higher Order Thinking Skills in Teaching of Science: A case study in Malaysia. International research Journal of Education and Sciences (IRJES), 1(1), 1-3.

Tan, S. Y., \& Siti Hajar, H. (2015). Effective teaching of Higher-Order Thinking (HOT) in education. The Online Journal of Distance Education and e-Learning, 3(2), 41-47.

The World Bank. (2013). Malaysia Economic Monitor: High Performing Education.

Tuan Mastura, T. S., Kamisah, O., \& Nurazidawati, M. A. (2012). M-21 CSI: A validated $21^{\text {st }}$ century skills instrument for secondary Science students. Asian Social Science, 8(16), 38-44.

Tyagi, S. (2013). A study of teaching effectiveness of Secondary school teachers in relation to their demographic characteristics. International Journal of Engineering and Innovative Technology, 3(1), 288-295.

Yaro, I., Rozita, A., \& Dani, S. (2017). Relevance of stakeholders in policy implementation. Journal of Public Management Research, 3(1), 1-16. https://doi.org/10.5296/jpmr.v3i1.10632

Yee, M. H., Jailani, M. Y, Widad, O, Razali, H, Tee, T. K., \& Mimi, M. M. (2012). The needs analysis of learning higher order thinking skills for generating ideas. Procedia - Social and Behavioral Sciences, 59, 197- 203. https://doi.org/10.1016/j.sbspro.2012.09.265

\section{Copyright Disclaimer}

Copyright for this article is retained by the author(s), with first publication rights granted to the journal.

This is an open-access article distributed under the terms and conditions of the Creative Commons Attribution license (http://creativecommons.org/licenses/by/3.0/). 